\title{
Kişladan Araziye: 1910 Osmanlı Sonbahar Manevrası
}

\section{From the Barracks to the Field: The Ottoman Manoeuvre of Fall 1910}

\author{
Zeynep Sabanc1 ${ }^{1}$ (1)
}

'Dr. Öğr. Üyesi, Adana Alparslan Türkeş Bilim ve Teknoloji Üniversitesi, Adana, Türkiye

\section{ORCID: Z.S. 0000-0002-8445-379X}

Sorumlu yazar/Corresponding author: Zeynep Sabancı,

Adana Alparslan Türkeş Üniversitesi Siyasal Bilgiler Fakültesi, Uluslararası Illişkiler Bölümü Adana, Türkiye

E-posta/E-mail: zsabanci@atu.edu.tr

Başvuru/Submitted: 07.01.2020 Revizyon Talebi/Revision Requested: 12.02.2020

Son Revizyon/Last Revision Received: 05.05.2020

Kabul/Accepted: 10.05 .2020

Online Yayın/Published Online: 03.07.2020

Atıf/Citation: Sabancı, Zeynep. "Kışladan Araziye: 1910 Osmanlı Sonbahar Manevrası." Osmanlı Bilimi Araştırmaları 21, 2 (2020): 271-291. https://doi.org/10.26650/oba.568826

\section{öz}

Çalışmamızda, muharebe eğitiminin önemli bir parçası olarak kabul edilen arazi talimleri, diğer bir deyişle mevsimlik manevralar ve bunların Osmanlı askeri mekanizması içindeki yeri tartışılacaktır. Tartışmanın ekseninde, 1910 senesinin Ekim ve Kasım aylarında icra edilen ve Osmanlı ordusunun ilk kez düzenlediği sonbahar manevrası yer almaktadır. I. ve II. Kolordu'nun katılımı ile gerçekleştirilen manevra için İstanbul-Edirne hattı arasında Lüleburgaz ve Babaeski mevkileri seçilmiş ve dört gün süren çarpışmaların ardından görkemli bir resmigeçit töreni ile son bulmuştur. 1910 Sonbahar Manevrası, arazinin analizi ve coğrafi imkân ve imkânsızlıkların önceden belirlenmesi açısından da ehemmiyetlidir. Bu bağlamda araştırmamız, gerçek savaş koşulları kurgulanarak düzenlenen manevranın Balkan savaşlarına giden süreçte ordu teşkilatının kapasitesi ve sınırlarını, savaşın patlak vereceği muhtemel coğrafyada tecrübe edebileceği yegâne faaliyet olduğunu ortaya koymaktadır. Temel kaynaklarımız, manevraya bizzat iştirak eden Von der Goltz Paşa'nın raporları, mektupları ve görüşleri ile 1910 Sonbahar Manevrasının konu edildiği Osmanlıca eserler ve T. C. Cumhurbaşkanlığı Devlet Arşivleri Başkanlığı Osmanlı Arşivi'nden edinilen belgelerdir.

Anahtar sözcükler: Askeri eğitim, Manevra, Savaş Oyunları, Alman Askeri Misyonu, Colmar von der Goltz, Goltz Paşa

\section{ABSTRACT}

The fall manoeuvre of October-November 1910 carried out by the Ottoman army is at the core of this study. Field drills were conducted around the towns of Lüleburgaz and Babaeski, located between İstanbul and Edirne. The manoeuvres lasted for two months, included four days of combat and ended with a spectacular parade. This was a stunning experience for the military officials and the soldiers because these manoeuvres enabled them to analyze the field and predict the geographical conditions of the terrain. Hence, this study argues that it was a unique experience which revealed the capacity and the limits of the Ottoman army in a prospective military zone and on the eve of the Balkan Wars. The primary sources are the reports and letters written by Von der Goltz Pascha, the Ottoman works on the Fall Manoeuvre of 1910 and the archival documents kept in the Ottoman Archives of the Presidency of the Turkish Republic's State Archives.

Keywords: Military education, Manoeuvres, War games, German military mission, Colmar von der Goltz, Goltz Pasha 


\section{Giriş}

On dokuzuncu yüzyılın ordularda öne çıkardığı yenilik genel bir ifade ile askeri örgütlenmeydi. Diğer bir deyişle, savaşçılık mesleğinin temelini teşkil eden kişisel cesaret ve cengâverlik yerini emir-komuta zinciri içinde biat eden neferin disiplininin ve eğitiminin üstünlüğüne bıraktı. Bu dönüşüm neferin kışla içi eğitimine, talim faaliyetlerine de yansıdi.

Osmanlı'da kışla eğitimi eskiden beri yeniçeri ve cebeci ocağında yapılagelmekteydi. Talimler düzenli ve daimiydi, ancak uzun bir süre atış talimleri ve bedensel kuvveti arttırmak adına yapılan idmanlar ile sınırlı kaldı. ${ }^{1}$ Örnek olarak, III. Selim döneminde (1789-1808) Haliç kıyısında kurulan ve içinde önce Hendesehane'yi sonra da Mühendishâne-i Berrî-i Hümâyun'u barındıran Humbarahane Kışlası'nda yapılan humbaracı talimleri verilebilir. Bu talimler, obüs toplarının süratle doldurulup atılmasını, topların bir yerden diğer bir yere seri bir şekilde nakledilmesini ve nişangâh açısı hesabını kapsıyordu. Ayrıca, humbaracılar araba koşmak, koşum bağlamak, araba tamir etmek ve gerçek barut kullanmadan atış yapmak (kuru talim) gibi faaliyetlerde bulunuyorlard ${ }^{2}{ }^{2}$

Avrupa'nın talimli ve düzenli orduları ile rekabet edebilmenin koşulu olarak askeri kurumların 1slahı, III. Selim döneminde devlet ricali ve ulemanın risale ve lâyihalarında öncelikli meseleydi. Nizam-1 Cedid projesinin de sac ayaklarından biri olan askeri yenileşme çalışmalarında, askerlerin talim, terbiye ve disiplin sınırları dışına çıkmamaları için şehrin muhtelif yerleri kışlaya dönüştürüldü. Beydilli, kışlaların genellikle şehrin boş ve ücra mahallerinde inşa edildiğini, böylece yeniçerilere alternatif olarak askere alınanların eski ocak mensupları ile temaslarının sınırlandırıldığını belirtir. ${ }^{3}$ Nitekim kışlalar, askerleri kışla dışı hayattan soyutlayacak şekilde tasarlanmıştı. ${ }^{4}$ Askerlerin tüm ihtiyaçlarının karşılandığı bu mekânlar, nefer/erkek nüfusun tek tip ve itaatkâr bireyler olarak düzenli talimler ile savaşa hazırlandıkları yerlerdi. Bunlar, ilerleyen dönemlerde kitle ordularını savaş meydanlarına çıkarmadan önce devletlerin, askerlik hizmeti ile yükümlü genç erkek nüfusu seferberliğe hazırladıkları asker ocakları olacaktı. Öte yandan askeri eğitimde atılan modern adımlar, araziyi okumaya yönelik çalışma alanlarının müfredata eklenmesini sağladı. Örneğin topografya ve kartografya okumaları, askerin arazi üzerindeki yürüyüş hızını arttırdığı gibi askere manevra kabiliyeti kazandıran eğitsel uygulamalar olup, bunlar eğitimde yenilikçi yaklaşımlardı.

1 Fatih Yeşil, İhtilâller Çağında Osmanlı Ordusu, Osmanlı İmparatorluğu'nda Sosyoekonomik ve Sosyopolitik Değişim Üzerine Bir İnceleme (1793-1826) (İstanbul: Tarih Vakfı Yurt Yayınları, 2016), 59.

2 Mustafa Kaçar, "Osmanlı Devleti’nde Bilim ve Eğitim Anlayışındaki Değişimler ve Mühendishanelerin Kuruluşu”" (Doktora Tezi, İstanbul Üniversitesi), 1996.

3 Kemal Beydilli, "Küçük Kaynarca'dan Tanzimat'a Islahat Düşünceleri," Illmi Araştırmalar: Dil, Edebiyat, Tarih İncelemeleri Dergisi 8 (1999): 30.

4 Yeșil, İhtilâller Çağında Osmanlı Ordusu, 96. 
$\mathrm{Bu}$ çalışmada muharebe eğitiminin önemli bir parçası olarak kabul edilen arazi talimleri, diğer bir deyişle mevsimlik manevralar ve bunların Osmanlı askeri mekanizması içindeki yeri tartışılacaktır. Tartışmanın ekseninde 1910'un Ekim ayında başlayan ve Osmanlı ordusunun ilk kez düzenlediği sonbahar manevrası bulunmaktadır. Çalışmada, Goltz Paşa'ya (Colmar Freiherr von der Goltz, 1843-1916) ait mektuplardan, raporlardan, askerliğe dair görüşlerini dile getirdiği metinlerden ve Osmanlı manevralarını anlatan matbu eserlerden faydalanılmıştır.

Manevra, askerin kışla dışına çıkarak, araziyi tecrübe ettiği, stratejik ve taktiksel eğitimini harp mekânı olarak kurgulanan bir coğrafyada gerçekleştirdiği eğitsel bir faaliyetti ve Alman eğitim sisteminden devşirilmişti. Osmanlı nezdinde ise, Alman subaylar eşliğinde uzun soluklu bir eğitimden geçmekte olan subaylar için manevra faaliyeti, askeri okullarda okutulan talimnamelerin araziye uygulanmasıydı. Diğer taraftan bu talim faaliyeti, yoğun katılıma sahne olmuş, bu nedenle yabancı gözlemciler tarafından da ilgiyle izlenmiştir. Manevralar, 1910'da Jön Türkler tarafından yeniden göreve getirilmiş olan Von der Goltz Paşa’nın gözetim ve yönetiminde gerçekleşti. Nitekim Osmanlı askeri eğitimi, on dokuzuncu yüzyılda Askeri Okullar Müfettişliğine atanan Alman subaylarının önerileri ile şekilleniyordu. Subayların ilk tespiti, savaşan askerlerin büyük çoğunluğunun arazi eğitimi almamış olmasıydı. Dolayısıyla askeri manevralar ile, askerin seferberlik öncesinde araziye hâkim olma, mesafeyi tahlil etme ve en önemlisi emir-komuta mekanizmasını gerçeğe yakın cephe koşulları içinde tecrübe etme imkânı yaratılacaktı. Söz konusu yetkinliklerin Osmanlı neferi tarafından tam anlamıyla sindirilmemiş olduğu aşikârd1, bu nedenle sonbahar manevrası büyük bir önem taşıyordu. Çalışmamızda 1910 Sonbahar Manevrası, faaliyetin fikir babası ve planlayıcısı olan Goltz Paşa'nın askeri raporları vasıtasıyla kendi gözünden anlatılacak ve iki kolordu halinde gerçek savaş koşulları içinde muharebe eden askerlerin, cenk ve harp usullerini ne derece yerine getirdikleri değerlendirilecektir.

\section{Haydi Asker, Araziye!}

Prusyalıların Kriegsspiele (Savaş Oyunları) geleneğinden gelen manevralar, geniş bir askeri talim tanımı verir ve içinde cephe gezilerini, tatbikat gezileri (zabitan seyahatlerini) ve yürüyüş talimlerini barındırır. ${ }^{5}$ Alman subay eğitiminin önemli bir parçası olarak kabul edilen savaş oyunlarına Napolyon Savaşları'ndan (1803-1815) önceki dönemlerde bile rastlanmaktaydı. Bu oyunlar, gelecekte orduya komuta edecek subayların yetişmesi ve Auftragstaktik (görev tipi emir) sisteminin geliştirilebilmesi için önemliydi. ${ }^{6}$ Zira von Moltke (Helmuth Graf von Moltke, 1800-1891) ve von

5 David Ian Hall, "The Modern Model of the Battlefield Tour and Staff Ride: Post-1815 Prussian and German Traditions," Defence Studies 5, 1 (2005): 94.

6 Hans Ehlert Gerhard Gross and Michael Epkenhans, International Perspectives on the German Strategy for 
Schlieffen' in (Alfred Graf von Schlieffen, 1833-1913) mütemadiyen atıfta bulundukları bir eğitim faaliyeti olan manevra ve savaş oyunları, 1815'den sonra Almanya'nın askeri mekanizmasına sistematik bir şekilde dâhil edilmişti. ${ }^{7} \mathrm{Ne}$ var ki, manevra geleneği Büyük Friedrich döneminde (1740-1786) bile Prusya askeri sistemi içinde yer bulmuştu.

Ordunun kendi içindeki eğitim faaliyetlerine büyük önem veren Büyük Friedrich, on sekizinci yüzyıl savaşlarının manevra ve ateş gücü ile kazanılacağının bilinci ile büyük çapta askeri tatbikatlar düzenlemiştir. Zira cephede başarı, düzenli talim ve arazi eğitimi ile kazanılacaktı. Bunun için taktiğe dayalı hareketlilik, ateş altında sebat etmek ve komuta kademesine sonsuz biat etmek gerekiyordu. ${ }^{8}$ Eşzamanlı olarak komutan da eğitime tabi tutuluyordu. Özellikle arazi talimine yönelik harita okuma ve tahkimat eğitiminin subay yetiştiren okulların ders programlarında bulunması elzemdi. Prusya askeri eğitim sisteminde subaylar kışın harita üzerinde çalışır, bahar ve yaz aylarında ise tatbikat gezilerine ve mevsimlik manevralara katılırlardı. Keşif gezilerinde subaylar, araziyi iyi tahlil etmeli, ister piyade ister süvari olsun atış menzilini takdir yetkisine sahip olmaliyd $1 .^{9}$

Manevra boyunca savaşın harekât planlaması yapılır, Aufmarschanweisungen (savaş düzeni alma direktifleri) üzerinde çalışılırdı. Kaldı ki harekât planlaması, orduların hacmi genişledikçe önem kazanıyordu. Zira askeri personel ve nefer sayısı arttıkça, kitleleri kontrol altına almak zorlaşırdı. On dokuzuncu yüzyıl sonunda Prusya ordusunun başına geçen Moltke mesafelerin uzunluğu göz önüne alındığında, büyüyen orduları cepheye sevk etme hususunda nakliye problemleri ile birlikte lojistik ile ilgili sorunların da ortaya çıktığını söyler. Diğer taraftan kendisinin halefi olan Schlieffen, meşhur planında düşmanı (Belçika-Fransa sınırında Fransız ordusunu) çevreleyerek imha etme stratejisi izler. Schlieffen'e göre çevreleme savaşları (battles

WWI. There was a Schlieffen Plan: New Sources on the History of German Military Planning (Kentucky: University Press of Kentucky, 2014), 86.

7 Hall, "The Modern Model of the Battlefield Tour," 94.

8 Büyük Friedrich'e göre ordu içinde vuku bulabilecek en ufak bir disiplinsizlik, barbarlığa neden olacaktı. Bu anlamda ataerkil bir disiplin anlayışının hâkim olduğu ordu (asker ocağı), en kıdemlisinden en kıdemsizine neferi otoritenin var ettiği bir nesneye dönüştürmeyi hedefliyordu. Disiplin ile uysallaştırılan asker, talim ve terbiye ile sisteme güçlü bir şekilde bağlanacaktı. Bk. Robert R. Palmer, "Frederick the Great, Guibert, Bülow: From Dynastic to National War," Makers of Modern Strategy; Military thought from Machiavelli to Hitler, haz. Edward Mead Earle (Princeton: Princeton University Press, 1948) içinde, 55.

9 Hall, "The Modern Model of the Battlefield Tour," 95. 1859'da Kriegsakademie (Harp Okulu) olarak modernize edilen subay mektebinde tatbikat gezileri, üç senelik teorik bilginin ardından üç haftalık bir program dâhiline yapılırdı. Bu gezilerin amacı, teorik bilgiyi arazide tecrübe etmekti. Alman Genel Kurmayı bünyesinde aktif hizmete alınacak olan subaylar, bu gezileri başarıyla tamamlayan adaylar arasından seçilirdi. Bk. Martin Samuels, Command or Control? Command, Training and Tactics in the British and German Armies, 18881918 (London: Franc Cass, 2003), 22-25. 
of envelopment), sonucu belirleyen muharebe (decisive battle)ile son bulmaliyd.$^{10}$ $\mathrm{Bu}$ da ancak düşman kuvvetlerinin imha edilmesi (war of annihilation) ile mümkün olacakt1. ${ }^{11}$

Yukarıda kısaca bahsedilen savaş oyunları ve manevraların genel özelliklerini Osmanlı'nın on dokuzuncu yüzyılda güncellediği Mekteb-i Harbiye müfredatlarında kısmen görmek mümkündür. Kaldı ki askeri manevralar, Osmanlı'nın Balkanlardaki hasımları ve Rusya tarafindan da on dokuzuncu yüzyılda askeri modernleşme çerçevesinde ele alınmaktaydı. Osmanlılar, muharebe öncesi güç gösterisine dönüşen bu faaliyetlerin sınır dışı uygulamalarından muhbirler vasıtasıyla haberdar oluyordu. ${ }^{12}$ Öyle ki askeri eğitimin bir parçası olarak talim ve beden terbiyesi küresel anlamda önem kazanarak, merkezi gücün, kendi ordusu ile kopmaz bir bağ oluşturmasına vesile oluyordu. ${ }^{13}$ Diğer bir deyişle, sisteme biat eden, Osmanlı monarşisine ve hilafet kurumuna sadık, silahlı bireyler yetiştirmek için öncelikle askeri okullar ve bu okulların müfredatları ele alındı. ${ }^{14}$

Osmanlı zabitan mekteplerinde edindiği teorik bilginin yanı sıra, Osmanlı askeri, zihinsel ve bedensel anlamda asıl kışlada şekillenecekti. Acemi neferin zihinsel terbiyesinde padişaha, vatana, millete sadakat, itaat, cesaret, namus, silah arkadaşlarına iyi davranma, kışla sınırları içinde kendisine aşılanan meziyetlerdi. Zira orduya alınmaları, askerleri toyluktan yetişkinliğe geçirmekteydi. Mâdûn olan rütbesi küçük asker, mâfek olan üst rütbeli askere itaat etmeliydi. Hatta onun yap dediğini yapmalı, yapma dediğini yapmamalıyd $1 .{ }^{15} \mathrm{Bu}$, aslında profesyonel ve kontrollü bir ordu oluşturmanın ilk koşuluydu. Güçlü bir ordunun oluşabilmesi için en küçük bölükten en büyük askeri birliğe kadar emirkomuta-kontrol üçlüsünün etkin çalışması gerekiyordu. ${ }^{16}$

Askerlik görevi için ordu hizmetine alınan bireyler, öncelikle bedensel yetenekleri göz önüne alınarak silahlı ve silahsız memuriyet yapmak üzere ayrılırdı. Bu uygulamanın

10 Gerhard P. Gross, The Myth and Reality of German Warfare, Operational Thinking From Moltke The Elder to Heusinger, (Kentucky: University Press of Kentucky, 2016), 86-99.

11 Gross, The Myth and Reality of German Warfare, 103-105.

12 Bulgar ordusunun 1905 yılının mart ayında Şipka civarında gerçekleştireceği askeri manevranın bilgisi Rupçaz Kaymakamı tarafından Rumeli’ye gönderilen muhbirler vasıtasıyla alınmıştır. Bahsi geçen rapora göre, on sene için seçilen bekâr Bulgar efradının ve redif ihtiyatlarının 15 gün içinde celbine karar verilmiş, civar köylerde yaşayan ahali de silahlandırılmıştır. Bk. T. C. Cumhurbaşkanlığı Devlet Arşivleri Başkanlığı Osmanlı Arşivi (BOA), Sadaret Eyâlât-1 Mümtâze Kalemi Belgeleri (A.MTZ) 159-45. Konu ile ilgili olarak bk. Gültekin Yıldız, Osmanlı Devleti'nde Askeri İstihbarat (İstanbul: Yeditepe Yayınevi, 2019).

13 Sanem Yamak Ateş, Asker Evlatlar Yetiştirmek, II. Meşrutiyet Dönemi’nde Beden Terbiyesi, Askeri Talim ve Paramiliter Gençlik Örgütleri (İstanbul: İletişim Yayınları, 2012), 58.

14 Odile Moreau, Reformlar Çă̆ında Osmanlı Imparatorluğu, Askeri “Yeni Düzen” in Insanlarl ve Fikirleri: 1826-1914, çev. Işık Ergüden (İstanbul: İstanbul Bilgi Üniversitesi Yayınları, 2010), 43.

15 Mehmed Ali, Acemi Neferin Terbiye-i Askeri Muallimi (Dersaadet: Cihan Matbaas1, 1326), 6.

16 BA-MA (Bundesarchiv-Militärarchiv), Bemerkungen über die während der Herbst-und Winter Übungen beim 1., 2. und 3. Kaiserlich Ottomanischen Ordu gemachten Wahrnehmungen, Ende Dezember 1909 (Aralık sonu 1909), İstanbul. 
hususları talimnameler ile belirlenmiş olup, bedensel yetenekleri silahsız memuriyete daha uygun görülen askerler sağlık veya fen hizmetlerinde görevlendirilirdi. Askerler depo, ambar, sanayi taburlarına alınır veya askeri fabrikaların üretim süreçlerinde istihdam edilirdi. Zira dericilikte ve fabrikalarda makinist olarak görev alanların bedensel olarak sağlam ve kuvvetli olmaları beklenirdi. Silahlı hizmete tefrik edilenlerin ise öncelikle bedensel muayeneleri yapılır, daha sonra bunlar silahlı hizmete tam veya kısmi kabiliyetli olanlar diye ikiye ayrılırdı. ${ }^{17}$ Diğer taraftan asker, silahı ile bütünleşebilmek için talim faaliyetlerine düzenli katılmalıydı. Zira askerin tüfeğine karşı vazifeleri vardı (Asker bana silahını göster, sana nasıl asker olduğunu söyleyeyim!). Asker, silahını daima temiz tutacak, her türlü fenalıktan saklayacak, koğuş dışında bulunduğu zamanlarda başkasının eline geçmemesine dikkat edecek, silahı koyacağı yerin tozlu ve çamurlu olmamasına özen gösterecekti. Kısacası, kendi öz bakımına dikkat ettiği kadar silahının bakımına da dikkat edecekti. ${ }^{18}$

Büyük çaplı askeri tatbikat ve arazi talimlerinin eğitim programına yerleştirilmesi için Goltz Paşa'nın önemli çalışmaları vardır. Paşa, 1909 senesinde, Meşrutiyet'in ilanından hemen sonra gözlem yapmak amacıyla İstanbul'a gelmişti. Goltz, orduda subay ve astsubay sayısının çok az olduğundan yakınmaktaydı. Subayların birçoğu 13 Nisan 1909'daki kanlı isyanda (31 Mart Vakası) hayatını kaybetmişti. Diğer taraftan ittihatçı kadro, II. Abdülhamid ve eski rejim taraftarı birçok alaylı subayı da ordudan ihraç etmişti. Yeni rejimin amacı subay profilini tamamen değiştirmekti, fakat bu arzu kısa vadede başarılı sonuçlar alabilmek için yeterli olmadi. ${ }^{19}$ Ayrıca, talim arazileri hijyen ve bakım açısından son derece kötü durumdaydı. Von der Goltz, arazi ile ilgili izlenimlerini şöyle aktarıyor; “Arazi talimleri ile ilgili bende oluşan ilk intiba, okul müfredatlarına uygun bir şekilde talim derslerinin yapıldiğ $l$, fakat arazi talimlerine yeterli klymet verilmediği idi. Talim arazileri kir, pas ve toz, duman içindeydi ki bu bende arazilerin atıl kaldı ̆̆ izlenimini uyandırdı." Eski öğrencileri ile talim bölgesinde istişarelerde bulunan Goltz Paşa, talim bölgesinin kullanılmamasına o kadar içerleyecekti ki küçük bir ordu birliğine hemen orada kısa bir atış talimi yaptırdı. ${ }^{20}$

II. Abdülhamid'in gizli polis teşkilatı ile kurduğu baskıcı ve şüpheci ortamda kafalarını kışladan dışarı çıkaramayan askerler için II. Meşrutiyet'in görece özgür ortamına atıfta

17 Hidmet-i Askeriyye Kabiliyyet-i Bedeniyye Muayenesine Aid Talimatname (İstanbul: Matbaa-1 Askeriyye), 6.

18 Mehmed Ali, Acemi Neferin Terbiye-i Askeri Muallimi, 8.

19 Gül Tokay, "Osmanlı' da Modern Devlet, Güvenlik Siyaseti ve Ordunun Dönüşümüne Dair Bir Değerlendirme," Türkiye'de Ordu, Devlet ve Güvenlik Siyaseti, haz. E. B. Paker ve İ. Akça (İstanbul: İstanbul Bilgi Üniversitesi Yayınlar1, 2010), 43.

20 BA (Bundesarchiv), v. Goltz, Bericht; das Generaloberst Freiherrn von der Goltz über seinen Aufenthalt in der Türkei Juli/August 1909, 28 Ağustos 1909, Berlin Halensee, 2. Goltz Paşa, henüz daha ordudaki görevinin ilk yıllarında iken Mekteb-i Harbiye talebeleri için yılsonu imtihanlarından hemen sonra yaklaşık on gün süren küçük manevralar düzenlemeyi tavsiye etmiştir. Bk. BOA, Yıldız Tasnifi Mütevenni Maruzat (Y.MTV) 17-51. 
bulunan Goltz Paşa, raporuna talim faaliyetlerindeki aksaklıkların son bulmadığını not edecekti. Alman subay, 23 Temmuz 1909'un güneşli bir sabahında büyük bir kalabalığın katılımı ile kutlanan Meşrutiyet'in birinci yıldönümünde şunları yazar; "Yaklaşık 6000 ila 8000 neferin katıldiğ resmigeçit, yetenekli kumandan Mahmut Muhtar Paşa'nın işareti ile başlamıştı. Yürüyüşs sırasında topçu birlikleri oldukça düzenli hareket ediyorlardı, diğer taraftan süvari bölüğ̈̈nün resmigeçit yürüyüs esaslarını tam olarak yerine getiremediğini tespit ettim. Askerlerin geçişine hararetli bir şekilde alkışlarla eşlik eden Osmanlı halkı, bu sıra dişı tiyatro piyesinin en neşeli unsuruydu. "21

Goltz, 28-30 Temmuz 1909'da Makriköy (Bakırköy) ve Davud Paşa civarlarında yaklaşık 60-70 kişilik bir asker topluluğunun katılımı ile birlikte küçük çaplı bir arazi çalışması yaptı. Çalışmaya bazı yüksek rütbeli subaylar da eşlik etti. Geçmiş dönemlerdeki çalışma koşulları göz önüne alındığında, Goltz, hareket kabiliyetinin nispeten arttığını, bu ufak talim faaliyeti için neredeyse hiçbir merciden izin almasına gerek kalmadığını yazar. Benzer tatbikatlar, 4 Ağustos'ta İstanbul'da, 9 Ağustos 1909 tarihinde ise Edirne'de tekrarlanmıştır. Gelişmiş silahların talim fişekleri' ${ }^{22}$ ile birlikte kullanıldığı bu tatbikatların Goltz Paşa'da bıraktığı intiba genellikle olumludur. Araziye hâkimiyet ve rütbeli subayların liderlik meziyetlerini oldukça yerinde bulmuştur. Diğer taraftan, tüm bu arazi çalışmaları bazı subayların girişimleriyle yapılmaktaydı. Zira faaliyetler, merkezden yönlendirilmiyor veya herhangi bir program dâhiline alınmıyordu. Dolayısıyla kayıt dışı kalan bu arazi talimleri, genelde Alman ekolüne göre yetişmiş birkaç subayın liderliğinde gerçekleşiyor, talimler askerlerin iştiraki açısından hem hacimsiz kalıyor hem de bunların devamı gelmiyordu.

Harbiye Nazırı Mahmud Şevket Paşa ile bir sene sonra Rumeli Kavağı'nda bir araya gelen Goltz Paşa, Ramazan ayına denk gelen bir sonbahar akşamında sahil bataryasının atış talimini izledi. Talimler sabit ve hareketli hedefler belirlenerek yapılmıştı ve kısmen başarılıydı. Zira beklentiler düşük tutulmuştu, çünkü subaylar ve bölük yeterince tecrübeli değildi. Görüldüğü gibi arazi ve atış talimleri küçük bölükler seviyesinde kalıyordu. Kolordular düzeyinde kapsamlı bir manevranın düzenlenmesi için 1910 senesine kadar beklemek gerekecekti.

21 BA, v.Goltz, Bericht; das Generaloberst Freiherrn von der Goltz über seinen Aufenthalt in der Türkei Juli/ August 1909, 28 Ağustos 1909, Berlin Halensee, 9.

22 Tatbikatlarda kullanılacak olan fișekler, harp fișeklerinden ayrı olarak üretilmekte veya satın alınmaktaydı. Elimizdeki en erken belgeler, Osmanlı hükümetinin 1873 senesinde Amerikan Winchester firmasından 2 milyon adet kurusıkı ve manevra fișeği satın aldığını gösteriyor. Bk. Zeynep Sabancı, "Osmanlı Askeri Teknolojisi ve Silahlanma Politikası" (Doktora Tezi, Mersin Üniversitesi, 2016) 99. İlerleyen zamanlarda ise Osmanlılar, diğer mühimmat alımları ile birlikte manevra müddetince kullanacakları cephaneyi de Alman silah fabrikalarından temin etmişlerdi. Örneğin, 1908'de Mauser fabrikasına 300 milyonu harp, 10 milyonu ise manevra fişeği olmak üzere toplam 310 milyon adet fişek sipariş edilmişti. Bk. BOA, İdari Askeri (İ.AS) 77/1. 


\section{Osmanlı Sonbahar Manevrası}

Sonbahar manevrası, aslında bir senelik bir hazırlanmanın (talim-terbiye) sonunda gerçekleştirilen bir genel tatbikattı. Genellikle yaz sonuna kadar bölüklerin münferit talimleri son bulur, sonbaharda ise gerçek savaş koşulları yaratılarak tatbikat yapılırdı. Manevrayı müteakip acemiler bölüklere yerleştirilir, aynı talim döngüsü kış bitene kadar devam ederdi. Manevra, Ramazan ayının bitişiyle ve I. ve II. Kolorduların katılımıyla 1910 Ekim ayının ilk günlerinde resmen başladı. ${ }^{23}$ Bundan yaklaşık bir ay önce tugay birlikleri nezdinde müfreze tatbikatı askeri garnizonlarda gerçekleşmişti. Büyük manevraya katılım oldukça yüksekti; yaklaşık 70.000 asker tatbikata katıldı. Balkan Savaşları arifesinde Osmanlı'nın barış zamanı askeri kuvvetlerinin 280.000 olduğu tahmin edilirse, ${ }^{24}$ savaş koşulları dışında gerçekleşen bir talim faaliyetine bu derecede asker sağlamak ciddi bir başarıydı. Sadece birkaç bin askerin bu sayı dışında bırakıldığını belirten Goltz Paşa, II. Abdülhamid döneminde askerlerin deyim yerindeyse kışla içine hapsedildiğini, gerek münferit gerek birlik talimlerinin (atış ve arazi) engellendiğini, hatta askerlerin küçük gruplar halinde bir araya gelmelerinin dahi mümkün olmadığını yazar. Zira birlik talimleri veya tatbikat gezileri genellikle son dakikada iptal edilirdi. ${ }^{25}$

Sadece askeri çevrelerde değil, tüm İstanbul halkı nezdinde büyük yankı uyandıran sonbahar manevrası, şehri kasıp kavuran kolera salgınına rağmen İstanbul-Edirne hattı arasında Lüleburgaz ve Babaeski mevkileri civarında başladı. Manevrayı İstanbul halkına haftalık olarak Şehbenderzâde Filibeli Ahmed Hilmi tarafından neşredilen Hikmet dergisi duyuruyordu. Dört gün sürecek olan manevranın Harbiye Nazırı Mahmud Şevket Paşa, Erkan-1 Harbiye-i Umumiyye Reisi İzzet Paşa ve von der Goltz Paşa tarafından ortaklaşa idare edileceği bilgisi verilmişti. Manevraya iştirak eden nefer sayısı, bir önceki yıl Almanya'nın Wüttenberg eyaletinde gerçekleştirilen manevraya katılan asker sayısının neredeyse yarısı kadardı. Derginin İstanbullulara bir de müjdesi vardı: Manevra bitişinde Padişahın (V. Mehmed Reşad) da hazır bulunacağı bir resmigeçit töreni düzenlenecekti. Tören, İstanbul-Edirne hattı arasında Lüleburgaz'ın güneyinde Seyitköy civarında yapılacaktı. ${ }^{26}$

Manevrada Garp Ordusu, Bulgar kuvvetini temsil ediyordu. II. Ordu komutanı Abdullah Paşa'nın sevk ve idaresinde olan bu kuvvetler, silahlanarak ve seferberlik hazırlıklarını

23 Mehmed Hûlusi (Yüzbaşı), Şark Ordusu 1326 Sonbahar Manevrast- Müşâhedât ve Mütâlaât (İstanbul: Matbaa-i Hayriyye, t.y.)

24 Mehmet Beşikçi, "Bir Yenilginin Anatomisi: Balkan Harbi'nde Osmanlı Seferberliği, 1912-1913," Yeni Bir Askeri Tarih Özlemi, Savaş, Teknoloji ve Deneysel Çalışmalar, haz. Kahraman Şakul (İstanbul: Tarih Vakfı Yurt Yayınları 2013) içinde, 297-310.

25 BA, gez. Frhr. v.d. Goltz, Bericht des Generaloberst Freiherrn von der Goltz über seinen Aufenthalt in der Türkei im Oktober und November 1910, 18 Aralık 1910, Berlin Halensee, 14.

26 “Manevra Münasebetiyle," Hikmet 24 (20 Ramazan 1326 / 29 Eylül 1910): 3. 
tamamlayarak Edirne üzerinden sınırı geçtiler. Plan, bu mevkide Türk kuvveti olarak temsil edilen Şark ordusu ile harp etmekti. Zeki Paşa komutasında ivedilikle seferber olan Türk kuvvetine ait bölükler, sürpriz atak karşısında İstanbul'a döndüler. Zira Zeki Paşa'nın öncelikli planı, zamansız gelişen saldırılara karşı savunma ile karşılık verip, geri çekilmekti. Goltz Paşa'nın ifadesine göre, harp edilen alan gerçek bir cepheyi yansıtmaktaydı ve her iki taraf da hücuma dayalı bir strateji benimsemişti. ${ }^{27}$ Manevranın ilk gününü keşif ve yürüyüşe ayıran birlikler daha sonraki günlerde gerçeğe oldukça yakın bir şekilde cenk ettiler ve muharebe esnasında gerçek silah ve mühimmat kullandılar. ${ }^{28}$

Manevra sahasına atanan hakemler talimleri tetkik etmekle görevliydi. Hakemlerin manevralardaki görüşleri önemliydi, zira manevra hakiki harplere ne kadar benzer bir şekilde yapılırsa sonuç o kadar başarılı olacaktı. Kaldı ki, atış tesiri olmayacağından askerler normal şartlarda yapmayacakları hareketleri ve/veya hücumları yapabilirlerdi. Bu gibi hadiselerin önünü almak için hakemlerden istifade etmek elzemdi. Öte yandan, Osmanlı subayı üzerinde önemli bir etkisi bulunan ve 1905 senesinde vuku bulan Rus-Japon savaşının hakemler tarafından iyi telakki edilmesi salık verilirdi. Tüm zabitlerinden ise hakemlik vazifelerini tahsil etmeleri ve hakem talimatnamesine vakıf olmaları beklenirdi. ${ }^{29}$

\section{Yürüyüş ve Keşif}

Askeri manevralarla ilgili yayın, yorum ve gözlemlerin yer aldı̆̆ en önemli husus, birliklerin manevra mıntıkasına düzenledikleri yürüyüş hazırlığı ve keşif faaliyetleriydi. Bu nedenle barış döneminde yapılan taktik ve tatbikat gezileri (zabitan seyahatleri) oldukça önemliydi. Zira gerçek savaş koşullarında muharebeyi sevk ve idare için genel yükümlülükler ve kurallar yoktu. Dolayısıyla komutanın tecrübesine, takdir ve öngörü yetisine ve arazi bilgisine göre içinde bulunduğu durumu tetkik etmesi gerekiyordu. ${ }^{30}$

Diğer taraftan yürüyüş (marschieren), belirli kural ve kaideler çerçevesinde gerçekleşmeliydi. Gerçek savaş koşullarında yürüyüş ve uygun adım kurallarının belirleyiciliği vardı. Muharebe sırasında, piyade birliklerinin hızlı hareket etmesi, seri ve güvenli bir şekilde

27 Mesut Uyar ve Edward J. Erickson, Osmanlı Askeri Tarihi (İstanbul: Türkiye İş Bankası Kültür Yayınları, 2017), 457.

28 BA, gez. Frhr. v.d. Goltz, Bericht des Generaloberst Freiherrn von der Goltz über seinen Aufenthalt in der Türkei im Oktober und November 1910, 18 Aralık 1910, Berlin Halensee, 14.

29 Mehmed Hûlusi, Şark Ordusu , 13. 1326 manevrasında Harbiye Nazırı Mahmud Şevket Paşa umum başhakem, Ferik Hüsnü Paşa Şark Ordusunun, Ferik Münir Paşa Garp Ordusunun umum hakemi olarak görev yapacaktı. Diğer taraftan Ferik İzzet Fuad Paşa, umum süvari hakemi olarak görev yapacaktı. Ayrıca, topçu, fen işleri, sıhhiye birlikleri için de birer hakem görevlendirildi. Erkan-1 Harb Miralayı Pertev, 1326 Sene-i Rumisinde Birinci ve İkinci Ordu-yı Hümayunlar Arasında İcra Edilen Sonbahar Manevrası (İstanbul: Kütüphane-i Askeri, 1328), 32.

30 Beşinci Kolordu Kurmay Başkanlığg Harekât Şubesi 2. Kısım, Taktik Tatbikat Gezisi (Ankara: Genelkurmay Basimevi, 1995), 24. 
savunma hattına yerleşmesi gerekiyordu. Zira piyade neferinin vazifeye başladığı ilk günden itibaren öğrenmek durumunda olduğu nokta, yürüyüş esnasında uzun ve rahat adımlar atmaktı. Yürüyüşün temel esası olan bu kural, askerlere kitleler halinde hızlı hareket etme imkânı tanıyacaktı. ${ }^{31}$ Kaldı ki hızını kaybeden asker, amacını ve niyetini kaybedebilir ve düşman kuvvetlerine karşı bir adım geriye düşebilirdi. Bu durumda komuta eden subayın veya daha yüksek rütbeli bir askerin yönlendirmesi, hareket hızını besleyen hayati bir meseleydi. ${ }^{32}$ Diğer taraftan piyade alayının ortalama bir saat içinde düşman kuvvetlerinden bir kilometre öteye konuşlanması gerekiyordu. Bu şekilde hem düşmanı kapsam altına alacak hem de onu arkada bırakacaktı. Goltz Paşa, bir piyade alayının yaklaşık 50 kilometre (yaklaşık 10 saat) hatasız bir şekilde yürüyüş kapasitesine sahip olması gerektiğini belirtmekteydi. ${ }^{33}$ Özellikle savunma savaşlarında hızlı mevzilenmenin önemi daha da artardı ve bunun mutlaka barış zamanında yapılacak genel tatbikatlarda tecrübe edilmesi gerekirdi.

Yürüyüş ve mevzilenme sırasında harp düzenini etkileyen önemli bir unsur da askerlerin yanlarında bulundurmak zorunda oldukları muhtelif ağır eşyaydı. Askerler iki tip ağırlık ile yola çıkacaklard1; cephane ve iaşeleri için temin edilen erzak ambarları. Manevra müddetince her bir piyade neferine 10, istihkâm neferine 5 ve makineli tüfek neferine 200 adet manevra fişeği temin edilecektỉ ${ }^{34}$. Diğer taraftan topçulara da top başına 90 , süvari neferine 50 , istihkâm neferine 40 ve makineli tüfek için $1800^{35}$ adet manevra mermisi verilecekti. Her top sadece 10 manevra hartucu sarf edebilecekti. ${ }^{36}$ Askerlere yürüyüş esnasında muhtelif ağır eşyanın yüklendiği arabalar eşlik edecekti. Yaklaşık 400-500 efradın oluşturduğu taburlar,

31 BA, v.d. Goltz, Bemerkungen über die während der Herbst-und Winter Übungen beim 1., 2. und 3. Kaiserlich Ottomanischen Ordu gemachten Wahrnehmungen, Ende Dezember 1909 (Aralık sonu 1909), İstanbul, 7.

32 Joseph Radetzky von Radetz, Feld-Instruktion für die Infanterie, Kavallerie und Artillerie (Olmütz: Alois Skarnitzl, 1844), 40.

33 BA, v.d. Goltz, Bemerkungen über die während der Herbst-und Winter Übungen, 9. Savaş müddetince gün aşırı harp eden birlikler için 50 kilometrelik mesafenin gerçekçi olamayacağı konusunda görüşler mevcuttur. Bunun için askerin iyi talim görmüş olması ve periyodik yapılan askeri manevralara iştirak etmesi gerekiyordu. Örneğin Çanakkale muharebesinde büyük kayıplar veren 15. Piyade Tümeninden geriye kalan askerler ihtiyat konaklama merkezine ulaşabilmek için yaklaşık 25 kilometrelik bir mesafeyi kat etmek durumunda kaldılar ve ertesi gün hummalı bir şekilde hazırlanan harekât planına dâhil oldular. Bkz. Edward J. Erickson, Gelibolu Osmanlı Harekâtı (İstanbul: Türkiye İş Bankası Yayınları, 2015), 145.

34 Mehmed Hûlusi, Şark Ordusu, 13.

35 Elbette bu miktarlar gerçek savaş koşulları ele alındığında oldukça düşüktü. Dönemin koşullarında $4000 \mathrm{~m}$ veya daha yakın mesafeden gelen topçu atışlarına karşı piyade veya süvarilerin karşı koyma ihtimalleri oldukça azdı. Örneğin dört büyük toptan oluşan bir sahra bataryası dakikada 6000 adet şarapnel ve mermiyi tek seferde düşman birlikleri üzerine yağdırabilirdi. Böyle bir durumda atışın \%1 oranında isabet etme olasılığı bile bölük içinde 60 kişiyi etkisiz hale getirebilirdi. Bk. BA, v.d. Goltz, Bemerkungen über die Während der Herbst-und Winter Übungen, 20.

36 Pertev, 1326 Sene-i Rumisinde, 11. Manevraya iştirak edecek olan taburların cephane ihtiyacı firkalar dâhilinde ikmal edilecek olup, fırka ve kolordu manevrası sırasında endaht tatbikatı için her nefer kişi başına 5 adet mermi sarf edebilecekti. Geri kalan mermiler, büyük ordu manevrası için saklanacaktı. Zira ordu manevrası sırasında mermi ihtiyacı fazla olduğundan askerlere mermi zayiatı vermemeleri salık veriliyordu. Bk. Pertev, 1326 Sene-i Rumisinde, 15. 
küçük ağırlık olarak çadır ve çadırların nakli için tesis edilmiş arabalar, ${ }^{37}$ sıhhi malzemelerin taşındığı Japon arabaları ve su sevkiyatı için hazırlanan tek beygirli saka arabaları (su arabaları) ile birlikte hareket edecekti. Büyük ağırlıkların taşındığı kumandan eşya arabası, karargâh heyeti eşya arabası ve yedek binek hayvanları, taburları arkadan takip edecekti. Her on nefer için bir çadır ve her on çadır için bir çadır arabası tahsis edilecekti. ${ }^{38}$ Ayrıca askerlerin üzerinde matara, ekmek torbası; nişancı taburunda her neferin üzerinde taşınabilir çadır ve yemek pişirmek için kap ve iki günlük peksimet bulunmaktaydı. ${ }^{39}$

Diğer taraftan Şark ve Garb orduları bünyesinde bulunan her bir firka, manevra coğrafyası içinde belirli merkezlerde bulunan erzak ambarlarını kullanırdı. Örneğin manevranın ikinci ayında Çerkezköy ile Araklı arasında tatbikat yapan II. Müretteb Fırka, Bursa Redif Fırkası, Müstakil Süvari Livası, I. Müretteb Fırka ve Samsun Redif Fırkasından oluşan Şark Ordusu Çerkezköy, Çorlu ve Tekfur dağı civarında konuşlanmış olan erzak ambarlarını kullanacaktı. ${ }^{40}$

Sonuç olarak, von der Goltz’a göre birliklerin yürüyüş düzeni genel olarak tatmin edici olmakla birlikte geliştirilmeye müsaitti. Yürüyüş sırasında askerlerin düştükleri hatalardan biri, korunaklı birer sığınak aramak için fazlaca zaman kaybetmeleriydi. Goltz Paşa, aşırı ihtiyatlı davranmanın en az ihmalkârlık kadar tehlikeli olduğundan dem vuruyordu. Dolayısıyla yürüyüş ve keşif, basit ve naif olmalı, askerler yürüyüş esnasında gereksiz kahramanlıklar yapmamalıd $1 .{ }^{41}$

37 Mehmed Hûlusi, Sark Ordusu, 13.

38 Pertev, 1326 Sene-i Rumisinde, 12.

39 Pertev, 1326 Sene-i Rumisinde, 15.

40 Pertev, 1326 Sene-i Rumisinde, 18. Muhtemelen erzak depolarının bulunduğu mahalleri gösteren cetveller manevra öncesinde askerlere dağıtılıyordu. Askerlerin yanında yedek tayınatı (yarım okka peksimet ve hayvanlar için beş kilo yemden oluşur) vardı ve bunu sadece acil durumlarda kullanmakla mükelleftiler. Zira sefer ve manevra öncesinde kendilerine verilen iki-üç günlük yedek tayınatı, subayları tarafından izin verildiği takdirde ancak yiyecek bulmak mümkün değilse tüketebileceklerdi. Dolayısıyla askerin emir almaksızın yanında bulunan erzakı tüketmesi veya atması halinde, askeri teçhizatını veya silahını atmış gibi ceza göreceği belirtiliyordu. Ahmed Ali, Illeri Karakol, Piyade Keşif Kollarl, Manevra Kavaidi, Konak ve Ordugâh Hidmeti, İaşe, Ağırlıklarda Efradın Suret-İ Hareketi (Dersaadet: Mekteb-i Harbiye Matbaası, 1326), 72. Yedek tayınatın nasıl tüketileceğine dair fikir veren bu talimata Mehmed Hûlusi de değinir. Manevra sırasında İstanbulÇerkezköy hattı arasında yürüyüş ve keşif faaliyeti yapan Şark Ordusu, Mürettep I. Fırkadan bazı askerler, henüz İstanbul'dan fazla uzaklaşmadan yanlarındaki yedek peksimetleri tüketmişlerdi. Mehmet Hûlusi, harp koşullarında olsalardı bu neferlerin ceza alacağını yazmıştır. Bk. Pertev, 1326 Sene-i Rumisinde, 24. Erzak depolarının bulunduğu mahalleri gösteren cetvellerin askerlere dağıtımı muhtemelen yeni bir uygulamaydı ve 1910 manevrası ile ilk kez tecrübe ediliyordu. Zira iaşenin sefer zamanında sorunsuz bir şekilde temin edilmesi oldukça zordu. Bunun için levazım ve nakliye işlerinin düzenli olması gerekliydi. Gerçek savaş koşulları oldukça farklıydı, askerlerin Anadolu'dan cephelere sevkiyatını sağlayan demiryolu hatlarında sürekli asker sevk edildiğinden, erzak taşımacılığı yapılamıyordu. Dolayısıyla, efrat yiyecek ihtiyacını ya yürüyüş mahallinde bulunan konaklama yerlerinden ya da ahaliden karşılayacaktı. Manevralarda iaşe temini için iaşe kolları çalışır, bunlar tatbikat sırasında tarafsız sayılırdı. Fakat savaş koşullarında bu kolların işlemediğine tanık olunmuştur. Bk. Tolunay Sandıkçığlu, "Cihan Harbindeki İaşe Çıkmazına Galiçya'dan Bakış," Yemek ve Kültür 23 (2011): 7.

41 BA, v.d. Goltz, Bemerkungen über die während der Herbst-und Winter Übungen, 25. 


\section{Şark Ordusu Garp Ordusuna Karşı!}

Manevralar ${ }^{42}$ dost ve düşman kuvvetlerin simgelendiği birlikler arasında yapıllyordu. Fırkaların her birine 55 adet çift beygirli arabadan oluşan erzak kolları eşlik ediyordu. Diğer taraftan Muhtelit Üçüncü Fırka, Muhtelit Yirminci Fırka, Karahisar Redif Fırkası ve Süvari Livasından meydana gelen Garp Ordusu, firkaların her biri için temin edilen 60-70 adet çift beygirli arabadan ${ }^{43}$ oluşan erzak kolları ile birlikte hareket edecekti. Büyük ağırlıklar ise yürüyüş kolunu 500 metre uzaklıktan takip edecekti. Manevra faaliyeti 1910 Ağustosunun son günlerinde başladı. İstanbul ve çevresinde vuku bulan kolera salgını nedeniyle Şark Ordusuna katılması planlanan Erikli Fırkasının yerini Bursa Redif Fırkası almıştı. ${ }^{44}$

Her bir firka kumandanlığında, kumandanın yanı sıra, bir erkân-ı harp subayı, bir emir subay yardımcısı (mülhak) ve bir yaver mülazım bulunurdu. Sefer sırasında ise bu sayı elbette artıyordu. Harp sırasında vazife süresinin uzun sürmesi hasebiyle bir erkân-1 harp subayı, biri yüzbaşı ve biri mülazım olmak koşuluyla 2 adet mülhak subayı ve en az bir, icap ettiğinde iki veya 3 emir subayı ve bir karargâh kumandanı bulunmalıydı. ${ }^{45}$

Manevrada kuvvetler, kırmızı (düşman-Bulgar) ve mavi (dost-Osmanlı) çizgiler ile gösterilmekte olup, karşı karşıya yapılan atış (endaht) talimlerinde 100 metre uzaklık esası gözetilirdi. ${ }^{46}$ Zira daha kısa mesafeden yapılan atışlar sırasında askerlerin zarar görme

42 Ahmed Ali, manevra alanı seçilirken dikkat edilmesi gereken hususlar üzerinde durmuştu. Buna göre; manevra arazisi seçilirken mümkün olduğunca hanelerin, dükkânların, hayvanların, bahçelerin, küçük koru ve yeni dikilmiş ormanların bulunduğu yerler tercih edilmemeliydi. Ayrıca tatbikatlar, tütün tarlaları, küçük dutluklar, haşhaş tarlaları, bağlar ve yeni dikilmiş fidanlıkların bulunduğu alanlarda yapılamazdı. Bk. Ahmed Ali, Ileri Karakol, 41.

43 Arabalar günlük 40 kuruşa pazarlık edilmişti. 45 gün sürecek olan manevrada her bir araba için tahminen 15 lira harcanmıştı. Bazı subaylar, her sene böyle bir külfetin altına girmektense 10-15 liraya masraf edip alınan arabaları, 10 sene boyunca yerel halkın kullanımına sunacak ve her sene manevra veya genel seferberlik halinde arabaları ahalinden talep edecekti. On sene sonunda ise ahali bu arabalara ve araba hayvanına tamamen sahip olabilecekti. Böylece ordu, üç sene yapılacak masrafla on senelik masraftan kurtulacak ve harp zamanı için ordunun elinde yeterli sayıda araba ve hayvan bulunacaktı. Pertev, 1326 Sene-i Rumusinde, 20.

44 Pertev, 1326 Sene-i Rumisinde, 19.

45 Pertev, 1326 Sene-i Rumisinde, 17. Gerçek savaş koşullarında bu denli nizami seferberlik mümkün olamıyordu. Örneğin imparatorluğun ciddi eksiklikler eşliğinde girdiği I. Dünya Savaşı sırasında birliklerin çoğu son dakika yapılan değişiklikler nedeniyle hazırlıklarını tamamlayamadan bölgelere sevk edildi. Bunun yanında ordu, personel seferberliği hususunda gönüllülerin askere kaydedilmesi ile birlikte insan kaynağı sıkıntısı yaşamasa da ciddi bir subay eksikliği ile karşı karşıya kaldı. Savaş sırasında her yüz muharip askere bir buçuk subay düşmekteydi ki bu oldukça düşük bir rakamdı. Uyar ve Erickson, Osmanlı Askeri Tarihi, 485. Mehmed Hûlusi, sadece tatbikatlarda Almanların tek bir fırka dâhilinde 100 kişiyi (subay ve nefer) barındırdığını, bunlara 80 adet hayvan ve 14 erzak arabasının eşlik ettiğini belirtir. Pertev, 1326 Sene-i Rumisinde, 19.

46 Harp sırasında ise düşman hatlarına sızmak için geçerli mesafe genel olarak 500 ila 1000 metredir ki bu durumda bile takviye kuvvetlere ihtiyaç vardır. Örneğin Çanakkale muharebesinde, Gelibolu yarımadasının kontrolü için Osmanlıların taarruz harekâtı ile yürüttüğü planda Türkler, İtilaf kuvvetleri hattına en fazla 500 metreden sızmışlar, fakat bu sızıntılar yeterli takviye ile güçlendirilemeyince karşı taarruz ile geri püskürtülmüşlerdi. Her iki taraf da birliğini korumaya yönelik sürdürdügü taarruzları kontrol edememiş, taraflar büyük kayıplar vermişti. Bk. Uyar ve Erickson, Osmanlı Askeri Tarihi, 140. 
olasılığ̣ varken, özellikle 10-15 metreden ateş ediliyorsa, karşıdakinin etkisiz hale gelme olasılığı yüksekti. Endaht talimlerinden önce her neferin namlu içini ve tüfek mekanizmasını kontrol etmesi beklenirdi. Nefer, bilhassa namluda toz, toprak veya herhangi bir pisliğin bulunmadığına kanaat getirmeliydi. Eğer namlu temizlenmeden ateş edilirse, namluda şişme veya çatlama oluşabilirdi. Endaht taliminde flama göstermek zaruri idi. Piyade birliklerine karşı yapılacak olan atışlarda piyadeye kırmızı, süvariye beyaz flama gösterilirken, topçu birliklerine yapılacak olan atışlarda flama yere yatırılacaktı. $\mathrm{Bu}$ flamalar, firka kumandanlarının zimmetinde bulunacaktı. ${ }^{47}$

Manevrada yansıtılan temsili savaş hali, ${ }^{48}$ Garp Ordusunun hâlihazırda savaş halinde olan Şark Ordusuna, Edirne sınırından yaptı̆̆ı taarruz ile başladı. Ferik Zeki Paşa kumandası altında ordu, demiryolu vasitasiyla seferber olarak Ergene deresi gerisinde, takriben Istranca-Çerkezköy-Çorlu hattı üzerinde ilerleyerek arazi tahkimine başladı. Taraflar, Edirne muhasarasını tamamlayabilmek için karşılıklı taarruz halinde talim yaptılar.

Bahsi geçen manevra cetveline göre I. Kolorduya mensup I. Mürettep Fırkanın harp edeceği mahaller Kalfaköy, Yarımburgaz ve Isparta Kalesi civarı iken, II. Mürettep Fırka Kadıköy, Silivri ve Balabanlı Çiftliği civarında üç gün sürecek olan firka manevrası yapacaktı. Daha sonra her iki firka aralarında Çerkezköy ve Araklı civarında üç gün boyunca kolordu manevrası yapacaktı. Söz konusu tatbikatlar sonrasında manevra yerleri değiştirilerek, farklı araziler tecrübe edilecekti. Örneğin kolordu manevrasından sonra, I. Mürettep Fırka, Dersaadet-Büyük Çekmece-Silivri yolundan, II. Mürettep Fırka Dersaadet-Isparta KalesiÇatalca yolundan ilerleyerek manevra coğrafyasını değiştireceklerdi. ${ }^{49}$

II. Kolorduya mensup birliklerden III. Nizamiye Firkası, Edirne'nin güney ve güneybatısında Dereköy ve Kırıkkilise civarında üç günlük fırka manevrası yapacaktı. Kolordu manevralarından hemen sonra I. Ordudan I. Mürettep Fırka Çerkezköy’de, II. Mürettep Fırka Çorlu'da, Süvari Livası Büyükmanika'da ve II. Ordu'dan III. Muhtelit Nizamiye Fırkası Babaeski'de, XX. Muhtelit Nizamiye Fırkası Kırıkkilise'de toplanacaktı. Daha sonra her iki ordu arasında yürüyüş ve keşif günü de dâhil olmak üzere Ahmetbey köyü civarında dört

47 Ahmed Ali, İleri Karakol, 43. Manevralarda kullanılan arazinin büyüklüğü hasebiyle işaretlerin flama ile verilmesi zaman ve kuvvet tasarrufuna vesile olacaktır. Bu durum savaş koşullarında da aynen uygulanır. Zira etkili ateş altında yüz ile işaret vermek nadiren mümkün olacağından, karmaşık muharebe durumlarının anlaşılması için işaret flamaları veya kol hareketlerinden istifade edilir. Bk. Fatih Cebeci, "Mart 1328 (1912) Tarihli Osmanlı Piyâde Ta’limnâmesi Işı̆̆ında Son Dönem Osmanlı Piyade Eğitimi” (Yüksek Lisans Tezi, Cumhuriyet Üniversitesi, 2016), 31.

48 Goltz Paşa'ya göre manevrada mizansen bir savaş hali yansıtılsa da sistemli bir talim yapılabilmesi için gerçekçi bir tatbikat ortaya koymak gerekiyordu. Bunun için düşman birliklerinin tatbikatlarda yer almış olduklarını varsaymak gerekir. Gerektiğinde talim yapan askerler, düşman birliklerini saklandıkları yerden çıkarmalıdır. Fakat manevra sırasında karşılıklı esir alımı caiz değildir. Diğer taraftan askerlerin mesafe ve karşı birliklerin sayısını muhakeme etmeleri beklenir. Ayrıca, talimlerde hedef noktası, ateş tipi, ateş dağılımı ile ilgili bilgi edinmek zaruridir. BA, v.d. Goltz, Bemerkungen über die Während der Herbst-und Winter Übungen, 15.

49 Pertev, 1326 Sene-i Rumisinde, 5. 
gün sürecek olan büyük ordu manevrası gerçekleştirilecek ve sonbahar manevrası, Edirne Seyitler istasyon bölgesinde düzenlenecek olan resmigeçit ile sona erecekti. ${ }^{50}$

Osmanlı neferi için önemli bir eğitim faaliyeti ve tecrübesi olduğu gözlemlenen bu manevranın bir diğer özelliği de art arda gelen mağlubiyetler nedeniyle hevesi ve umudu kırılmış bir ordunun moralini yükseltmenin yanı sıra, devletin eski gücüne kavuşabileceğine ve belki de küllerinden yeniden doğacağına dair bir inanç yeşertmesiydi. Bu anlamda yer yer halkın ve ayrıca yabancı gözlemcilerin de takip etmesine izin verilen manevralar, başlı başına kamusal bir olay niteliğinde devam etti. Uzun süre kışla içine hapsedilen ve siyaset ile fazlasıyla meşgul olan Osmanlı subayının saygınlığını yitirdiği düşüncesi belki de bu büyük tatbikat ve sonrasında gerçekleştirilen görkemli resmigeçit ile bertaraf olacaktı. Dolayısıyla dönemin padişahının tören sırasında yerini almasına büyük bir önem atfedildi. Zira ordu kumandanlarının tören sonrasında sultanın huzurunda yaptıkları konuşmalarda, Osmanlı'nın geçmiş seferlerine yönelik romantik göndermeler yapılırken, hükümdarlarının askeri faaliyetlerde daha fazla söz sahibi olmasını arzu ettiklerine dair görüşleri büyük yankı uyandırdı. ${ }^{51}$

Manevrayı eserlerinde etraflıca anlatan Pertev Paşa, tatbikat faaliyetini "takdire şayan" ifadesiyle nitelendirmişti. Ayrıca, bu denli büyük bir manevraya dâhil olmak subay ve askerler arasında büyük bir haz yaratmış, seferberliğe ilişkin geçmişte yapılan hataların düzeltilebileceği düşünülmüştü. Diğer taraftan manevra arazisi için Edirne ve civarının düşünülmüş olması, uzun süredir işgal tehdidi altında bulunan bölge ahalisinin moralini yükseltmişti. ${ }^{52}$ Hatta resmigeçit sonrasında hükümdarın Edirne'ye düzenlediği bir haftalık seyahat bölge halkını memnun etmiş, ahalide Edirne geçilemez hissiyatı yerleşmişti. ${ }^{53}$

1910 Sonbahar Manevrasında Müslüman ahaliden celp edilen askerlerin yanı sıra Osmanlı'nın gayrimüslim unsurları da yer aldı. Açıkçası bu durum, 1908 Devrimi'nden sonra askere alma kanunlarında yapılan değişikliklerin bir sonucuydu. 1909 tarihli yeni celp kanununda, askerlik vazifesinin sadece Müslüman unsurlara hasredilemeyeceği belirtilmiş, gayrimüslimlerin vazifeye alınması hususunda adeta bir ileri bir geri giden süreçte sona gelinmesine karar verilmişti. Böylece Hıristiyan ve Yahudi tebaadan olan Osmanlı unsurlarının askerlikten muaf olmak üzere ödedikleri Bedel-i Askeri ianesi kaldırılmış ve

50 Pertev, 1326 Sene-i Rumisinde, 7. Goltz Paşa, Sultan Mehmed Reşat'ın da iştirak edeceği resmigeçit töreninin 27 Kasım'da manevraların bitişinden hemen sonra yapıldığını yazıyor. Goltz'un verdiği rakama göre resmigeçit törenine 40.000 kişi iştirak etmişti. Resmigeçit tecrübesine sahip olmayan askerler, hazırlık ve içtima için ziyadesiyle zaman harcamış, bu nedenle tören iki buçuk saatlik bir gecikme ile başlayabilmişti. BA, gez. Frhr. v.d. Goltz, Bericht des generaloberst Freiherrn von der Goltz über seinen Aufenthalt in der Türkei im Oktober und November 1910, 18 Aralık 1910, Berlin Halensee, 18.

51 BA, gez.Frhr. v.d. Goltz, Bericht des generaloberst Freiherrn von der Goltz über seinen Aufenthalt in der Türkei im Oktober und November 1910, 18.

52 Pertev, 1326 Sene-i Rumisinde, 91.

53 BA, gez.Frhr. v.d. Goltz, Bericht des generaloberst Freiherrn von der Goltz über seinen Aufenthalt in der Türkei im Oktober und November 1910, 19. 
askerlik vazifesi tüm Osmanlı unsurları için mecburi kılınmıştı. ${ }^{54}$ Goltz Paşa, bu durumu manevra notlarında değerlendirmiş, her iki unsurun manevrada yer almasına büyük önem atfetmişti. Ona göre tatbikat boyunca taraflar arasında herhangi bir husumet çıkmamış olması umut vericiydi. Kaldı ki askerlerin talimler boyunca dini vecibelerini yerine getirmelerine izin verilmişti. Din, orduda mahremiyeti olan bir alan olarak telakki edilmişti. Bunun talimlerde ortaya çıkması, her iki unsurun da kendileri için mukaddes olan cuma ve pazar günlerinde birbirlerine güzel dileklerini iletmiş olmasıydı $1 .{ }^{55}$

Manevranın teknik ayrıntılarına gelince, bu konudaki görüşlerini maddeler halinde etraflıca yazan Goltz Paşa'ya kulak vermek gerekir. Daha önce de belirtildiği gibi Osmanlı sonbahar manevrasını yönetmek ve değerlendirmek üzere padişah tarafından bizzat davet edilmiş olan Goltz Paşa, sonbahar manevrasından bir sene önce gerçekleştirilmiş olan tümen manevrasına ilişkin görüşlerini 1909 senesinin Aralık ayında yayımladığ 1 Bemerkungen über die während Herbst-und Winter Übungen beim 1., 2. und 3. Kaiserlich ottomanischen Ordu gemachten Wahrnehmungen (I., II. ve III. Kolorduların katılımıyla düzenlenen Osmanlı Sonbahar ve Kış Manevrası üzerine düşünceler) başlıklı makalesinde tartışmıştır. Görüşlerinde piyade, süvari ve topçu birliklerini ayrı ayrı ele alan Goltz Paşa'nın talimler ile ilgili genel düşüncesi olumludur. Öncelikle yürüyüş talimi konusunda birliklerin hiç de fena olmadığını yazar, fakat askerlerin uygun adım yürüyüşlerinin daha düzenli, güçlü ve nispeten daha hızlı olması gerektiğini söyler. Zira düzensiz ve yavaş yürüyüş, birliklerin toplanma mekânına zamanında ulaşamamasına neden olur. Goltz'a göre birliklerin komutanlarının güvenlerini kazanabilmesi için toplanma yerlerine ulaşmada kayıtsız şartsız dakik olmaları gerekir. ${ }^{56}$

Goltz Paşa, araziye hâkimiyet konusuna geniş yer ayırmıştır. Bilhassa, süvari, topçu ve piyade dâhil tüm bölüklerin araziye hâkim olmaları beklenir. Örneğin bir süvari askeri, iyi bir binici olmanın yanı sıra bir piyade neferi kadar keskin bir gözlemci olmalıdır. ${ }^{57}$ Uzak

54 Ufuk Gülsoy, "Osmanlı Gayrimüslimlerinin Askerlikten Muafiyet Vergisi: Bedel-i Askeri (1855-1909)," İstanbul Üniversitesi Edebiyat Fakültesi Tarih Dergisi 37 (2002): 118.

55 BA, gez.Frhr. v.d. Goltz, a.g.belge, 19. Balkan savaşları yenilgisinden sonra seferlere Müslüman ve Gayrimüslim unsurların omuz omuza çıkma ihtimali tamamen ortadan kalkmış, Gayrimüslimlerin askere alınmasına ilişkin bir türlü çözülemeyen sürecin sonuna gelinmişti. Kaldı ki I. Dünya Savaşı öncesinde yapılan cihat duyurusu ve Müslüman erkekleri silah başına davet eden propagandist söylemler, Müslüman olmayan unsurları vatan savunmasından azlediyordu. I. Dünya Savaşı öncesinde ilan edilen cihat söylemine yönelik tartışmalar için Bk., Jihad and Islam in World War I, Studies on the Ottoman Jihad on the Centenary of Snouck Hurgronje's "Holy War Made in Germany", yay. haz. Erik Jan Zürcher (Leiden: Leiden University Press, 2016)

56 BA, gez.Frhr. v.d. Goltz, Bericht des generaloberst Freiherrn von der Goltz über seinen Aufenthalt in der Türkei im Oktober und November 1910, 19.

57 Süvari bölüğü, yeterli miktarda küçük zabit ve neferi arazi keşfi için terbiye etmeliydi. Sefer sırasında bir küçük zabit ile iki nefer kâşif olarak tayin edilirdi. Bu kişiler, ivedilikle istihdam edilmek için bölük kumandanı veya daha büyük kumandanların yakınında bulunurlardı. Kâşif neferler, kumandanın Keşşaflar ileri! Ve Kumanda sende keşşaflar! emri üzerine dörtnal ile tayin olunan istikamette ileri çıkarlardı. Bk. Süvari Neferi Talimnamesi (İstanbul: Matbaa-1 Askeriyye, 1328), 28. 
mesafe görüşü kuvvetli olmalı, adeta bir topun gülleleri gibi hedefine kilitlenmelidir. Süvari aynı zamanda gerideki birlikleri düşman kuvvetleri ile ilgili olarak bilgilendirmekle yükümlü olduğu için kendisini iyi ifade etmeli ve tok sesi, en gerideki askere kadar ulaşmalıdır. ${ }^{58}$

Büyük manevralar ve mevsimlik askeri tatbikatlar, karmaşık silahların kullanıldığı, talim mermisi ile ateş edilse bile gerçek savaş koşullarını yansıtan karşılıklı atışların yapıldı̆̆ı talimlerdi. Manevra sırasında her nefere ayrı ayrı atış talimi yaptırılması mümkün olmadığından, en azından zabit ve küçük zabitlerin kışlada atış talimi tecrübelerinin olması beklenirdi. ${ }^{59}$ Özellikle piyade neferi ateşli silahlar ile ziyadesiyle bütünleşmeliydi. Piyade alayı 4000 m uzaklıktan araziye hâkim olmalı ve mümkün olduğu surette askeri mevzilerde konuşlanmış olan ve ateşe hazır bekleyen düşman ordusu karşısında görünmez olmalıydı. Her piyade askeri silahını iyi kullanmalı, kendi mühimmatının ustası olmalıyd. Asker, tek bir mermi bile ziyan etmeden her durumda silahını çabuk ve güvenli bir şekilde doldurmalı ve onu temiz tutmalıydı. Zira silahını gece vaktinde bile gün ışığında doldurduğu gibi çabuk doldurmalıydı. Mütemadiyen silah talimi yapmanın getirdiği en büyük fayda neferin yürüyüş halindeyken, ayakta veya yatar pozisyonda tüfeğini sorunsuz doldurabilmesiydi. ${ }^{60}$

Manevra aynı zamanda arazi keşif ve istihkâm çalışmalarının yapıldığı bir eğitim faaliyetiydi ve bu nedenle harp okullarında verilen harita okuma dersleri manevralarda tecrübe edilebilecekti. Zira askeri talim yapılmaksızın sadece harita üzerinde hayata geçirilmeye çalışılan düzenlemeler kişiyi yanıltabilirdi. Goltz Paşa, Osmanlı komutanlarının haritalara bağımlı kalarak yaptıkları stratejik düzenlemeleri eleştirirken, belirli ölçeklere göre yapılmış olan haritalarda mesafelerin birbirine yakın görünmesinin hatalı uygulamalara

58 BA, gez.Frhr. v.d. Goltz, Bericht des Generaloberst Freiherrn von der Goltz über seinen Aufenthalt in der Türkei im Oktober und November 1910, 17.

59 Osmanlı'da manevra öncesi talim devri, acemi askerlerin orduya katılması ile başlar ve bu döngünün yeniden başladığı tarihe kadar devam ederdi. Buna göre kış döneminde bölüklere yeni katılan acemi askerler münferit bir şekilde talim görür ve bu süreçte tecrübeli neferler, daha önce yaptıkları talimleri tekrar ederlerdi. İlkbahar dönemi tabur talimleri gerçekleştirilir, acemi neferler ile tecrübeli neferler birlikte talim yaparlardı. Yaz dönemi ise tabur, alay ve liva talimleri ile manevraya hazırlık talimlerinden oluşurdu. Cebeci, "Mart 1328 (1912) Tarihli Osmanlı Piyâde Ta'limnâmesi Işı̆̆ında Son Dönem Osmanlı Piyade Eğitimi," 111. Bireysel talimlerin önemine dönemin askeri neşriyatında sıkça yer verilmesine rağmen, uygulamada durum hiç de parlak görünmüyordu. 1910'da yapılan kolordu manevrasında hakem olarak görev alan Mustafa Kemal, 1911 senesinde kaleme aldığ1 ve daha sonra Zabit ve Kumandan ile Hasb-ı Hâl başlığı altında basılan notlarında, gerçek askerlik ilminin verileceği mekânın mektepten ziyade kıt'a olduğunu ve asıl sanat eğitiminin komutanlar tarafından verilmesi gerektiğini söylüyor. Zira Mustafa Kemal hakemlik yaptığı manevrada komutanların tesir gücünün oldukça zayıf olduğundan, bölük komutanlarının üst rütbelilerden aldıkları emirlerin içeriğini dâhi anlayamadıklarından yakınır. Bk. Kurmay Yarbay Mustafa Kemal, Zabit ve Kumandan ile Hasb-ı Hâl (Ankara: Genel Kurmay Askeri ve Tarih ve Stratejik Etüt Başkanlığı Yayınları, Genel Kurmay Basımevi, 2010), 11.

60 BA, gez.Frhr. v.d. Goltz, Bericht des Generaloberst Freiherrn von der Goltz über seinen Aufenthalt in der Türkei im Oktober und November 1910, 16. Piyade talimnamelerinde bu husus ayrıntıları ile anlatılır. Özellikle vücudun her vaziyetinde neferin süratli ve emniyetli bir şekilde silahını doldurabilmesi sıklıkla yapacağ talimlerle mümkün olur, nefer tatbikat ve manevralar sırasında daima talim fişeği kullanmalıdır. Cebeci, "Mart 1328 (1912) Tarihli Osmanlı Piyâde Ta'limnâmesi Işı̆̆ında,” 38. 
neden olduğuna dikkat çekmekteydi. Dolayısıyla, muharebe planları yapılırken harita ve arazi uygulamaları beraberce ele alınmalıydı. ${ }^{61}$

1910 Sonbahar manevrası tümen yapılanması, arazi kullanımı, taktik ve strateji geliştirilmesi açısından adeta Balkan savaşlarının bir ön provasıdır. Aynı sene, ordunun teşkilat yapısı, yeniden yapılandırma kararnamesi kapsamında Alman ekolünden gelen Ahmed İzzet Paşa'nın yönlendirmesiyle radikal bir şekilde değiştirilmiştir. Bu bağlamda modern bir birlik geometrisi olan ve henüz Avrupa ordu teşkilatında dahi kullanılmayan üçlü teşkilat yapısı benimsenmiştir. Buna göre, her tümen üç alaydan ve her alay da üç taburdan oluşacaktı. Böylece her biri üç tümen ve buna mukabil destek unsurlardan oluşan kolordu karargâhları ile yapılanma etkinleşiyordu. ${ }^{62}$ Sonbahar manevrasında bu yapılanmanın tecrübe edildiği görülmektedir. Daha önce de belirtildiği gibi iki kolordu ve karargâhı ile birlikte yapılan manevrada, her kolordu üç tümen ve yardımcı unsurlardan oluşuyordu. Şark Ordusu I. Mürettep Fırka, II. Mürettep Fırka ve Bursa Redif Fırkası olmak üzere üç tümenden, Garp Ordusu ise muhtelit III. Fırka, XX. Muhtelit Fırka ve Kara Hisar Fırkasından meydana gelmişti. ${ }^{63}$ Yapılanma, teşkilat yapısını küçültüyor, ama daraltmıyordu. Diğer taraftan, muharip unsurlar (piyade ve süvari alayı gibi), manevrada da görüldügüü üzere ön planda daha çok yer almış, topçu ve istihkâm birlikleri gibi destek unsurlar geri planda kalmıştı. Örneğin, I. Mürettep Fırka bünyesinde üç adet piyade alayı yer alırken, bir adet sahra topçu alayı ve 1 adet cebel bataryası bulunmaktaydı. ${ }^{64}$ Teşkilat yapısında radikal sayılabilecek bu yapılanmanın, sadece iki sene içerisinde yerli yerine oturmasını beklemek oldukça iyi niyetli bir öngörüydü.

\section{Sonuç}

1910 yılının Ekim ve Kasım aylarında gerçekleşen ve dört gün süren çarpışmaların ardından 27 Kasım 1910 tarihinde Sultan V. Mehmed Reşad'ın da katıldığı görkemli bir törenle sona eren Sonbahar Manevrası, savaş çığırtkanlığının yapıldığı bir dönemde, olası bir seferberlik ilanı öncesinde ordu teşkilatının kapasitesini ve sınırlarını görebildiği yegâne mekân olmuştu. Öyle ki tatbikat, arazinin tahlil edilmesi ve coğrafi bölgenin sunduğu imkân ve imkânsızlıkların önceden anlaşılması açısından önem taşıyordu. Nitekim Balkan devletleri ile var olan husumet, bir sonraki savaşın cephesini çoktan belirlemişti. Diğer taraftan manevralar, savaş eğitiminde talep edilen yeni becerilerin öğrenildiği ve uygulandığ 1 tecrübe mekânlarıydı. On dokuzuncu yüzyılın ikinci yarısından itibaren savaşın endüstriyelleşmesi ile askerlerin emir-komuta zinciri içinde buyruklara otomatik olarak boyun eğmesi yetersiz gelmeye başlamış, askerlerden verilen emirleri göz önünde bulundurarak mevcut durumu

61 BA, gez.Frhr. v.d. Goltz, a.g.belge, 25.

62 Uyar ve Erickson, Osmanll Askeri Tarihi, 442.

63 Pertev, 1326 Sene-i Rumisinde, 71.

64 Aynı yer. 
kollamaları ve ayaküstü yaratıcı çözümler üretebilmeleri beklenmiştir. ${ }^{65}$ Öyle ki bu yüzyılda gelişen savaş makineleri ile birlikte cephede çözüm üretecek potansiyel güç yine insan gücüydü. Orduyu insan gücünden mahrum birakan en büyük etmen ise eğitimli askeri personel noksanlığı ile birlikte firar sorunuydu.

Sonbahar Manevrası, Balkan savaşları öncesinde bu sorunu tüm çıplaklığı ile gözler önüne sermiştir. Manevrayı etraflıca yorumlayan askeri uzmanlar, firka kumandanlığının askeri personel açısından seferi bir teşkilata haiz olmadığını yazar. Diğer taraftan bir harp kadar uzun soluklu olmayan bir manevrada vazife karışıklığına sebep olmamak için haddinden ziyade zabitin görevlendirilmemesi gerektiği konusunda görüşler de vardı. Son tahlilde uzmanların görüşü; bir erkân-1 harp zabiti, biri yüzbaşı, biri mülazım olmak koşuluyla erkân-1 harp vazifesi yapabilecek iki mülhâk zabit (subay yardımcısı), asgari bir ve icabında iki veya üç emir zabiti ile bir karargâh kumandanının fırka kurmay heyetini oluşturması yönündeydi. Bunun yanında bir levazım memuru ile bir firka sertabibi de seferber olmaliyd1.

1910 kolordu manevrası, hâlihazırda yapılan diğer talim ve tatbikatlardan gerek süre açısından gerekse kullanılan cephane açısından da farklıdır. Öncelikle manevrada gerçek savaş koşulları yaratılarak süre uzatılmış, cephane olarak da manevra fişekleri kullanılmıştır. Arazi bakımından ise İstanbul sınırlarından başlayarak neredeyse tüm Trakya bölgesini içine alan geniş bir coğrafi alan kullanılmıştır. Bu alan içerisinde cephe parçaları ile sınırlı mıntıkalar yaratılmıştır. Diğer taraftan askerler, konaklayacakları mahallerin önceden harita üzerinde işaretlenmiş olmasıyla iaşeleri için gerekli olan ağırlıkları yürüyüş öncesinde bu seçilen yerlere göndererek, fazla yüklerinden kurtulmuşlar ve daha randımanlı bir yürüyüş talimi gerçekleştirmişlerdir. Gündüz yürüyüş ve karşılıklı cenk talimleri ile geçen tatbikat, geceleri askerler arasında bir nevi sosyalleşme etkinliğine dönüşen savaş, strateji oyunları ve satranç ile devam etmiştir. ${ }^{66}$

Manevrada, operasyona bağlı problemler uygulamalı olarak çözülmeye çalışılmış ve seferler senaryolar üzerinden kurgulanarak hatlar kırmızı ve mavi olarak belirlenmiştir. Ayrıca seferber olma ve mevzilenme üzerinde durulmuş, özellikle ihtiyat kuvvetlerinin demiryolu vasıtasıyla cepheye sevki tecrübe edilmiştir. Fakat sevk ve idarede yaşanan sıkıntılar, kuvvetlerin zamanında bölgeye ulaştırılmasını engellediği için onların yerine yardımcı kuvvetler kullanılmıştır.

65 Ulrich Bröckling, Disiplin, Askeri İtaat Üretiminin Sosyolojisi ve Tarihi, çev. Veysel Atayman (İstanbul: Ayrintı Yayınları, 2008), 41-42.

66 Bir senaryo üzerinden kurgulanan savaş oyunları ve tarihi canlandırmalar ile ilgili olarak bkz; Abdullah Turhal, "Tarihi Canlandırmak: Minyatür Figürler ve Savaş Oyunları ile Tarihin Yeniden Canlandırılmasının Tarih Öğretiminde Kullanılması," Yeni Bir Askeri Tarih Özlemi, Savaş, Teknoloji ve Deneysel Çalışmalar, haz. Kahraman Şakul (İstanbul: Tarih Vakfı Yurt Yayınları, 2013) içinde, 115-116. 
Sonuç olarak, 1910 Sonbahar Manevrası Batı'dan örnek alınan diğer savaş oyunları ve genel tatbikatlar gibi özellikle astsubayların manevra ve harp tecrübesi kazanmaları için kurgulanmış eğitsel bir faaliyetti ve barış zamanında ordunun işlevsel kapasitesi hakkında fikir vermesi açısından da oldukça önemliydi.

Hakem Değerlendirmesi: Dış bağımsız.

Çıkar Çatışması: Yazar çıkar çatışması bildirmemiştir.

Finansal Destek: Yazar bu çalışma için finansal destek almadığını beyan etmiştir.

Peer-review: Externally peer-reviewed.

Conflict of Interest: The author has no conflict of interest to declare.

Grant Support: The author declared that this study has received no financial support.

\section{KAYNAKÇA / BIBLIOGRAPHY}

\section{Arşiv Kaynakları / Archival Sources}

T.C. Cumhurbaşkanlığı Devlet Arşivleri Başkanlığı (BOA), Sadaret Eyâlât-1 Mümtâze Kalemi Belgeleri (A.MTZ) 159-45

BOA, Yıldız Tasnifi Mütevenni Maruzat (Y.MTV), 17-51.

Bundesarchiv-Militärarchiv (BA-MA), Bemerkungen über die Während der Herbst-und Winter Übungen beim 1., 2. und 3. Kaiserlich Ottomanischen Ordu gemachten Wahrnehmungen, Ende Dezember 1909 (Aralık sonu 1909), İstanbul.

Bundeasarchiv (BA), v.Goltz, Bericht; das Generaloberst Freiherrn von der Goltz über seinen Aufenthalt in der Türkei Juli/August 1909, 28 Ağustos 1909.

BA, v.Goltz, Bericht; das Generaloberst Freiherrn von der Goltz über seinen Aufenthalt in der Türkei Juli/ August 1909, 28 Ağustos 1909, Berlin Halensee.

BA, gez.Frhr. v.d. Goltz, Bericht des Generaloberst Freiherrn von der Goltz über seinen Aufenthalt in der Türkei im Oktober und November 1910, 18 Aralık 1910, Berlin Halensee.

\section{Basılı Kaynaklar / Printed Sources}

Ahmed Ali. Illeri Karakol, Piyade Keşif Kollarl, Manevra Kavaidi, Konak ve Ordugâh Hizmeti, İaşe, A ğırlıklarda Efradın Suret-i Hareketi. Dersaadet: Mekteb-i Harbiyye Matbaası, 1326.

Ateş, Sanem Yamak. Asker Evlatlar Yetiştirmek, II. Meşrutiyet Dönemi'nde Beden Terbiyesi, Askeri Talim ve Paramiliter Gençlik Örgütleri. İstanbul: İletişim Yayınları, 2012.

Beşikçi, Mehmet. "Bir Yenilginin Anatomisi: Balkan Harbi'nde Osmanlı Seferberliği, 1912-1913," Yeni Bir Askeri Tarih Özlemi, Savaş, Teknoloji ve Deneysel Çalışmalar. Hazırlayan Kahraman Şakul içinde 297310. İstanbul: Tarih Vakfı Yurt Yayınları, 2013.

Beşinci Kolordu Kurmay Başkanlığı Harekât Şubesi 2. Kısım, Taktik Tatbikat Gezisi, (Ankara: Genelkurmay Basımevi, 1995). 
Beydilli, Kemal. 'Küçük Kaynarca'dan Tanzimat’a Islahat Düşünceleri,” İlmi Araştırmalar: Dil, Edebiyat, Tarih Incelemeleri Dergisi 8 (1999): 25-64.

Bröckling, Ulrich. Disiplin, Askeri İtaat Üretiminin Sosyolojisi ve Tarihi. Çeviren Veysel Atayman. İstanbul: Ayrıntı Yayınları, 2008.

Cebeci, Fatih. "Mart 1328 (1912) Tarihli Osmanlı Piyâde Ta’limnâmesi Işı̆̆ında Son Dönem Osmanlı Piyade Eğitimi.” Yüksek Lisans Tezi, Cumhuriyet Üniversitesi, 2016.

Gross, Gerhard P. The Myth and Reality of German Warfare, Operational Thinking From Moltke The Elder to Heusinger. Kentucky: University Press of Kentucky, 2016.

Gross, Gerhard, Hans Ehlert and Michael Epkenhans. International Perspectives on the German Strategy for WWI. There was a Schlieffen Plan: New Sources on the History of German Military Planning. Kentucky: University Press of Kentucky, 2014.

Gülsoy, Ufuk. "Osmanlı Gayrimüslimlerinin Askerlikten Muafiyet Vergisi: Bedel-i Askeri (1855-1909).” Istanbul Üniversitesi Edebiyat Fakültesi Tarih Dergisi 37 (2002): 93-118.

Hall, David Ian. "The Modern Model of the Battlefield Tour and Staff Ride: Post-1815 Prussian and German Traditions." Defence Studies 5, 1 (2005): 93-102.

Jihad and Islam in World War I, Studies on the Ottoman Jihad on the Centenary of Snouck Hurgronje's "Holy War Made in Germany". Yayına Hazırlayan Erik Jan Zürcher. Leiden: Leiden University Press, 2016.

Kaçar, Mustafa. “Osmanlı Devleti’nde Bilim ve Eğitim Anlayışındaki Değişimler ve Mühendishanelerin Kuruluşu.” Doktora Tezi, İstanbul Üniversitesi 1996.

“Manevra Münasebetiyle,” Hikmet 24 (20 Ramazan 1326 / 29 Eylül 1910): 3.

Mehmed Ali. Acemi Neferin Terbiye-yi Askeri Muallimi. Dersaadet: Cihan Matbaas1, 1326.

Mehmed Hûlusi (Yüzbaş1), Şark Ordusu 1326 Sonbahar Manevrası, Müşâhedât ve Mütâlaât, İstanbul: Matbaa-1 Hayriyye, t.y.

Moreau, Odile. Reformlar Çă̆ında Osmanlı Imparatorluğu, Askeri 'Yeni Düzen' in Insanlarl ve Fikirleri: 1826-1914. Çeviren: Işık Ergüden. İstanbul: İstanbul Bilgi Üniversitesi Yayınları, 2010.

Mustafa Kemal [Atatürk]. Zabit ve Kumandan ile Hasb-ı Hâl. Ankara: Genel Kurmay Askeri ve Tarih ve Stratejik Etüt Başkanlığı Yayınları, 2010.

Öztan, Güven Gürkan. Türkiye'de Militarizm, Zihniyet, Pratik ve Propaganda. İstanbul: İstanbul Bilgi Üniversitesi Yayınları, 2014.

Palmer, Robert R. "Frederick the Great, Guibert, Bülow: From Dynastic to National War." Makers of Modern Strategy; Military thought from Machiavelli to Hitler. Hazırlayan Edward Mead Earle içinde 91-123, Princeton: Princeton University Press, 1948.

Pertev. 1326 Sene-i Rumisinde Birinci ve İkinci Ordu-yı Hümayunlar Arasında İcra Edilen Sonbahar Manevrası. İstanbul: Kütüphane-i Askeri, 1326.

Radetzky von Radetz, Joseph. Feld-Instruktion für die Infanterie, Kavallerie und Artillerie. Olmütz: Alois Skarnitzl, 1844.

Sabanc1, Zeynep. "Osmanlı Askeri Teknolojisi ve Silahlanma Politikası. "Doktora Tezi, Mersin Üniversitesi, 2016.

Sandıkçıŏlu, Tolunay. "Cihan Harbindeki İaşe Çıkmazına Galiçya’dan Bakış.” Yemek ve Kültür 23 (2011), 78-101. 
Samuels, Martin. Command or Control? Command, Training and Tactics in the British and German Armies, 1888-1918. London: Franc Cass, 2003.

Süvari Neferi Talimnamesi. İstanbul: Matbaa-1 Askeriyye, 1328.

Tokay Gül. “Osmanlı'da Modern Devlet, Güvenlik Siyaseti ve Ordunun Dönüşümüne Dair Bir Değerlendirme.” Türkiye'de Ordu, Devlet ve Güvenlik Siyaseti. Hazırlayan E. B. Paker ve İ. Akça içinde 35-47. İstanbul: İstanbul Bilgi Üniversitesi Yayınları, 2010.

Turhal, Abdullah. "Tarihi Canlandırmak: Minyatür Figürler ve Savaş Oyunları ile Tarihin Yeniden Canlandırılmasının Tarih Öğretiminde Kullanılması.” Yeni Bir Askeri Tarih Özlemi, Savaş, Teknoloji ve Deneysel Çalışmalar. Hazırlayan Kahraman Şakul içinde 109-122. İstanbul: Tarih Vakfı Yurt Yayınları, 2013.

Uyar, Mesut ve Erickson, Edward J. Osmanlı Askeri Tarihi. İstanbul: Türkiye İş Bankası Kültür Yayınları, 2017.

Yeşil, Fatih, İhtilâller Çă̆ında Osmanlı Ordusu, Osmanlı İmparatorluğu’nda Sosyoekonomik ve Sosyopolitik Değişim Üzerine Bir Inceleme (1793-1826). İstanbul: Tarih Vakfı Yurt Yayınları, 2016. 
